\title{
Prevalence of Lymphatic Filariasis in Ndiagu Ikenga Ogidi, Idemili North LGA, Anambra State Nigeria
}

\author{
Orji, N.M.
}

Department of Biological Sciences, Faculty of Natural Sciences, Chukwuemeka Odumegwu Ojukwu University, Anambra State, Nigeria.

E-mail: nm_orji@coou.edu.ng; Phoneno: +2348030921170

\begin{abstract}
This study was conducted to determine the prevalence of Lymphatic filariasis (Lf) amongst inhabitant of Ogidi in Idemili North Local Government of the Anambra State. Venous blood samples were collected from 104 randomly selected inhabitants from 10 communities and examined using standard parasitological methods. Standardized questionnaire were also administered immediately after blood samples collection to assess their age, sex, occupation and level of education. Results obtained showed an overall prevalence rate of $20.2 \%$. Infection rate was higher in males (23.07\%) than females (19.2\%). Age group amongst 41-50 years recorded highest prevalence rate of $35.7 \%$ while least infection was found among 10-20 years of age $(0.0 \%)$. Occupational -related prevalence of infection revealed that farmers had highest prevalence $(35.0 \%)$ of infection while unemployed had least prevalence $(1.9 \%)$ of infection. Analysis of the data showed a significant difference $(\mathrm{P}<0.05)$ in the prevalence of infection between respondents of different age and occupational groups. This study establishes the prevalence of Lymphatic filariasis in Ogidi, Idemili North LGA, Anambra State, Nigeria.
\end{abstract}

Original Research Article

Received: $11^{\text {th }}$ Dec., 2017

Accepted: $13^{\text {th }}$ Jan., 2018

Published: $14^{\text {th }}$ Mar., 2018

Keywords:

Lymphatic Filariasis

nematode worms

Wuchereria bancrofti

Brugiamalayi

Ogidi, Idemili North

\section{INTRODUCTION}

$\mathrm{L}$ ymphatic filariasis (LF) is a tropical disease caused by the parasitic filarial nematode worms, Wuchereria bancrofti, Brugiamalayi and Brugiatimori (Anosike et al., 2005). Of the 73 countries where Lymphatic filariasis is known to occur, 38 are in Africa and in this region infections are exclusively caused by W. bancrofti (Mba and Njoku, 2000). The third most endemic country for this disease after India and Indonesia is Nigeria, where bancroftian filariasis is 22.1\% (Addiss and Brady, 2007).

The visible manifestations of the disease are severe and disfiguring. Lymphoedema and elephantiasis of the limbs or genitalia, hydrocele and scrotal pathology in men, recurrent infections associated with damaged lymphatic and abnormalities of the renal function occur in an estimated 44 million people (Eigege et al., 2002).

Lymphatic filariasis results in loss of work, productivity, direct and indirect economic loss and functional impairment (Omudu and Okafor, 2007).Consequently the disease is a significant impediment to socio-economic progress of the endemic countries (Srividya et al., 2000). Unprecedented and unplanned urbanization, overcrowding and deteriorating sanitary conditions in both urban and rural areas is believed to be exacerbating the transmission of this mosquito borne disease in Nigeria (Terranella et al., 2006).

Infact its very obvious that lymphatic filariasis causes a severe mobility which is the second most important cause of permanent disability (Badaki and Akogun, 2001; Vandeu et al., 2013). Acute symptoms such as episodic adenolymphangitis cause severe physical suffering while the chronic conditions such as lymphedema and hydrocele cause permanent and psychosocial problem among others. Therefore, there is need to investigate the lymphatic filariasis prevalence amongst inhabitant of Ndiagu Ikenga Ogidi in Idemili North Local Government Area, Anambra state Nigeria.

\section{MATERIALS AND METHODS}

\section{Study Area}

The study was conducted in NdiaguI kenga Ogidi in Idemili North Local Government Area, Anambra State Nigeria. This Community is located about 90 kilometers from Awka, the state capital. It is situated between longitude $6^{\circ} 36^{\prime} \mathrm{E}-7^{\circ} 05^{\prime}$ 
E and Latitude $5^{\circ} 43^{\prime}-6^{\circ} 12^{\prime}$ North. It is characterized by two main seasons, the rainy and dry season. It has an annual mean temperature values of between $25^{\circ} \mathrm{C}$ to $33^{\circ} \mathrm{C}$. Most of the inhabitants belongs to Igbo ethnic group. The study population was made up of students, workers (both Public and Private) unemployed, traders, farmers.

\section{Collection of samples}

Ethical Consideration:

Prior to the collection of blood samples, permission was sought from head of the Community of Ndiagu Ikenga Ogidi, also consent of participants. Thereafter, a fixed date was agreed for sample collection.

One hundred and four blood samples were collected for this study, $2 \mathrm{ml}$ of venous blood samples were obtained from each participant into ethylene diaminetetraacetate (EDTA) anticoagulated bottles. The samples were labeled accordingly and taken to the laboratory for examination.

\section{RESULTS}

Of the 104 respondents examined for Lymphatic filariasis, 21 were positive for $W$. bancrofti microfilariae. This gave a prevalence of $20.2 \%$. Infection varied amongst age group. Statistical analysis of the age-related prevalence of lymphatic filariasis revealed that infection increases with age. This was
Questionnaire was administered to each respondent immediately from which personal information on age, level of education, occupation, knowledge and attitude was derived.

\section{Blood Samples examination}

Thick smear technique were used for this analysis according to (10). Two (2) mls of blood samples were placed on a clean grease free slide and a blood film was made on each sample. It was allowed to air dry and then stained with Giemsastain. It was then viewed under the microscope using X100 Objective.

\section{Statistical Analysis}

Data collected were analysed using the chi-square test $\left(\mathrm{X}^{2}\right)$ to compare and test for significance

found to be significant at $\mathrm{P}<0.05$. Persons within $10-20$ years of age had lowest prevalence rate of $0 \%$ while age $41-50$ years recorded highest prevalence rate of $35.7 \%$. Details are shown in Table 1.

The sex of the individuals at $\mathrm{P}<0.05$ variation did not have any influence on the prevalence of the parasite though lymphatic filariasis was found to have occurred more in males $(23.07 \%)$ than in females $(19.2 \%)$ Table 1

Table 1: Percentage Prevalence of Lymphatic Filariasis in age/sex groups in the study Area.

\begin{tabular}{lllllll}
\hline Age/sex Group & \multicolumn{2}{c}{ Male } & \multicolumn{2}{c}{ Female } & \multicolumn{2}{c}{ Total } \\
\hline $\boldsymbol{( \% )}$ & No. Examined & No. +ve (\%) & $\begin{array}{l}\text { No. } \\
\text { Examined }\end{array}$ & No. +ve (\%) & No. Examined & No. +ve (\%) \\
\hline $10-20$ & 2 & $0(0.0)$ & 6 & $0(0.0)$ & 8 & $0(0.0)$ \\
$21-30$ & 2 & $0(0.0)$ & 25 & $4(16.0)$ & 27 & $4(14.8)$ \\
$31-40$ & 10 & $2(20.0)$ & 29 & $7(24.1)$ & 39 & $9(23.1)$ \\
$41-50$ & 4 & $2(50.0)$ & 10 & $3(30.0)$ & 14 & $5(35.7)$ \\
$51-80$ & 8 & $2(25.0)$ & 8 & $1(12.5)$ & 16 & $3(18.6)$ \\
\hline Total & $\mathbf{2 6}$ & $\mathbf{6 ( 2 3 . 0 7 )}$ & $\mathbf{7 8}$ & $\mathbf{1 5 ( 1 9 . 2 )}$ & $\mathbf{1 0 4}$ & $\mathbf{2 1}(\mathbf{2 0 . 2})$ \\
\hline
\end{tabular}

Of the 104 inhabitants interviewed, farmers recorded highest prevalence with $38.5 \%$, followed by traders with $35.0 \%$. This was totally different to $54 \%$ that had no formal education. Most of the inhabitants interviewed were within the age bracket of 31-40years (38\%) while those of 0-20 years were the least in number with $7.7 \%$ respectively. Demographic characteristics of the inhabitants were recorded in Table 2.

\section{DISCUSSION}

This study has revealed a prevalence of $20.2 \%$ for Lymphatic filariasis. This shows that Lymphatic filariasis is an important Public Health problem in Ogidi as observed elsewhere in Nigeria (Gyapong et al., 1998). This could be attributed to inhabitants being exposed to mosquito bites, not using mosquito net and unhealthy environment. Water found in containers, potholes and all hollow materials that are found around giving mosquitoes the opportunity to breed. This agrees to the work of Obi et al. (2011); Wijesinghe et al. (2007)
Table 2: Demographic Characteristics of Inhabitants by Occupation, Educational level and Age group.

\begin{tabular}{lcc}
\hline Occupation & Frequency & Percentage \\
\hline Students & 10 & 9.6 \\
Farmers & 40 & 38.5 \\
Civil Servants & 16 & 15.4 \\
Traders & 36 & 35.0 \\
Unemployed & 2 & 1.9 \\
Total & $\mathbf{1 0 4}$ & $\mathbf{1 0 0}$ \\
& & \\
Education Level & & \\
No Formal Education & 56 & 54 \\
Primary Education & 22 & 21.2 \\
Secondary Education & 8 & 7.7 \\
Higher Education & 18 & 17.3 \\
Total & $\mathbf{1 0 4}$ & $\mathbf{1 0 0}$ \\
& & \\
Age Group & & \\
10-20 & 8 & 7.7 \\
21-30 & 27 & 26.0 \\
$31-40$ & 39 & 38.0 \\
41-50 & 14 & 13.5 \\
51-80 & 16 & 15.1 \\
Total & $\mathbf{1 0 4}$ & $\mathbf{1 0 0}$ \\
\hline
\end{tabular}


Results obtained also shows a variation in the distribution of infection in relation to sex, age, occupation and level of education as reported in similar studies (Orji et al., 2009). The high infection observed among the males could be attributed to their level of exposure to mosquito bites. Males usually engage in activities such as swimming, fishing and farming, thus exposing them to infection than their female counterparts.

Subjects within the age group of 31-40 years were most infected. They constitute the labour force. They usually engage to farming, trading and after the day's job the recreate by going to drinking places or bar which is usually in an open place where they are more exposed than other age group.

The low infection rate among those between the age group 10-20 years could be attributed to differences in behavior and lack of exposure.

Occupation plays a vital role in the distribution of Lymphatic filariasis. In this farmers were the most infected, followed by traders. This was attributed to the nature of their occupation. Their job brings them into contact with the vectors (Orji et al., 2009; WHO, 2011). Whereas the low infection rate observed among unemployed and students could be due to the nature of their work which restricts them from engaging in activities like farming, fishing thus are less exposed to infection.

The level of knowledge contributes to the dissemination of diseases (Anosike et al., 2005; Wijesinghe et al., 2007; WHO, 2011). In this research, inhabitants with no formal education recorded highest prevalence than others. Lack of information encourages failure. This agrees with the work of Obi et al. (2011); Orji et al. (2009). Poor or unhealthy environment favours the breeding of the intermediate host coupled with the nature of occupation of the peoples are factors that determines the transmission of lymphatic filariasis in the study area. Infection can be controlled through the proper disposal of empty containers, building irrigations, eradication of Mosquito intermediate host and health education on the relationship between exposure and infection.

\section{REFERENCES}

Addiss, D.G. and Brady, M.A. (2007). Mobility management in the global programme to eliminate Lymphatic filariasis: a review of scientific literature. Filarial Journal. 6(2):21-33.

Anosike, J.C., Nwoke, B.E.B., Ajayi, E.G., Onwuliri, C.O., Okoro, O.U., Oku,E.E., Asor,J.E., Amajuoyi,O.U and Meribe,C.O. (2005). Lymphatic filariasis among Ezza people of Ebonyi State, Eastern Nigeria. Annual Agric Environmental Medication. 12:181-186.
Badaki, J.A and Akogun ,O.B.(2001). Severe Morbidity due to Lymphatic filariasis in TarabaState,Nigeria. Nigeria Journal of Parasitology 22, 1 and 2:105-112.

Eigege, A., Richards, F.O., Blaney, D.D., Miri,E,E.S., Gontor,I., Ogah, G., Umaru.J., Janadu,M.Y., Matthias, W., Amadiegwu, S. and Hopkins, D.R.(2002). Rapid assessment for Lymphatic filariasis in Central Nigeria;a comparison of the immunochromatographic card test and hydrocele rates in an area of high endemicity.American Journal of Tropical Medicine Hygiene.68(6):643-646.

Gyapong, M., Webber, R.H.,Morris, J. and Bennetts, S.(1998). Prevalence of hydrocele as a rapid diagnostic index for Lymphatic filariasis. Transactions of the Royale Society for Tropical Medicine and Hygiene. 98:40-43.

Mba, D.C. and Njoku, O.O. (2000). Prevalence of Lymphatic filariasis in Oraeri, Anambra State, Nigeria. Journal of Parasitology. 21: 95-102.

Monica Chessbrough (1988). District Laboratory Practice in Tropical Countries (Part1).Cambridge University Press, Ukpp 457.

Obi, R.K., Nwanebu, C., Ndubuisi-Nnaji, U.U., Okangba, C.C., Braid,W.,Orji,N.M., Ukegbu,A.D and Ukegbu, P.O. (2011). Endemicity of Lymphatic Filariasis in three Local Government Areas in Imo State Nigeria. Australian Journal of basic and Applied Sciences. 5(5):875879.

Omudu, E.A. andOkafor,F.C. (2007). Rapid Epidemiological and Socio-cultural appraisal of Lymphatic filariasis amongst the Igede ethnic group in Benue State, Nigeria. Nigerian Journal of Parasitology. 28 (2):118-123.

Orji, N.M., Nwoke,B.E.B., Ukaga,C.N. and Dozie,I.N.S.(2009).Rapid Assessment of Endemicity of Loiasis in Onuimo and Abo Mbaise Local Government Areas, Imo State,Nigeria. Nigerian Journal of Parasitology. 30(2): 75-78.

Srividya,A.,Lau,R.,Ramaiah,K.D.,Ramu,K.,Hoti,S.L.,Pani,S.P. Das,P.K(2000). Development of Rapid assessment procedure for the delimutation of Lymphatic filariasis-endemic areas. Tropical medicine and International Health. 5(1):64-67.

Terranella, A., Eigege, A., Jinadu, M.Y., Miri, E. and Richards, F.O. (2006).Urban Lymphatic filariasis in Central Nigeria. Annual Tropical Medical Parasitology.100(1):1-10.

Vandeu Berg, H.,Kelly-Hope, L.A. and Lindsay, S.W. (2013). Malaria and Lymphatic filariasis:the case for integrated vector management. Lancet infectious disease. 13.89-94.

Wijesinghe, R.S., Wickremasinghe, A.R., Sriyam,A. and Perera,M.S.A.(2007). Physical disability and psychosocial impact due to chronic filarial lymphoedema in Sri-Lanka. Filarial Journal. 6:4-11.

World Health Organization (2011).Position Statement on managing mobility and preventing disability in GPELP. Who/HTM/NTD/PCT/2011.8. Geneva:WHO

\section{How to cite this article}

Orji, N.M. (2018). Prevalence of Lymphatic Filariasis in Ndiagu IkengaOgidi, Idemili North LGA, Anambra State Nigeria. Tropical Journal of Applied Natural Sciences, 2(2): 61-63. Doi: https://doi.org/10.25240/TJANS.2018.2.2.08 